\title{
Choose or Check-In: Gender Influence in Booking of the Luxury Hotels in Jaipur
}

\author{
Mukesh Shekhar, C. Anirvinna, Aravind Kumar Rai
}

\begin{abstract}
Accommodation is a main consideration which assumes a significant job in sustainability of tourism among the creating nations. The visitor basic leadership process in lodging determination particularly extravagance portion is impacted by such a significant number of components which incorporates climate, inn area, value, individual inclinations, etc. Along these lines, the principle reason for this investigation is to discover the job of gender in choice of lavish inns of Jaipur in context to tourism sustainability. To satisfy the motivation behind the examination, an aggregate of 200 visitors were chosen from five lavish lodgings of Jaipur visited in the previous one month and to evaluate the buyer basic leadership style of the visitors according to the sex, a self-built poll was utilized. To investigate the information Independent t-test was employed. Results uncovered that there was a critical effect of sexual orientation in determination of lavish lodgings in Jaipur. Therefore we can presume that sex factor to be contemplated for tourism sustainability.
\end{abstract}

Key Words : Luxury Hotel, Sustainability, Gender, Tourism, Jaipur

\section{INTRODUCTION}

India is a country that has tourism resources such as medical tourism, heritage tourism, adventure tourism including traditional and cultural activities, which are elements that attract lots of tourists to come and visit India and, therefore, bring about revenues worth many billions and its economic growth, including support for employment generation and distribution of income within communities.(1-4) As per Ministry of Tourism Foreign Tourist Arrivals (FTAs) during2017 were 10.18 million with a development of $15.6 \%$ over same time of the earlier year. During 2016, FTAs were 8.8 million with a development pace of $9.7 \%$ more than 2015 . In the year 2016, there were 5.77 million appearances of NRIs in India, with a development pace of $9.7 \%$ more than 2015. ITAs incorporate both FTAs and appearances of Non Resident Indians (NRIs). In the year 2016, there were 14.57 million International Tourist Arrivals (ITAs) in India, with a development pace of $9.7 \%$ more than 2015. Outside Exchange Earnings through Tourism (FEEs) during the period 2017 were Rs.1,80,379 crore with a development of $17 \%$ over same time of earlier year. The FEEs from tourism in rupee terms during 2016 were Rs.1,54,146

Revised Manuscript Received on December 15, 2019.

* Correspondence Author

Mukesh Shekhar, Assistant Professor, School of Hotel

management, Manipal University Jaipur

Dr C. Anirvinna, Assistant Professor, School of Hotel management, Manipal University Jaipur

Aravind Kumar Rai, Assistant Professor, School of Hotel

management, Manipal University Jaipur crore with a development pace of $14.0 \%$.

Therefore, tourism industry is an important strategy as it will be used by the government to upgrade the country's economic development; to attract the consumer it is fundamental that organizations get purchasers and their basic leadership as they try to increase an upper hand.

Those managers with an unmistakable apparition of purchaser requirements will endure and advance. Tragically, promoting research in lodgings is still chiefly restricted to the examination of visitor related information, in light of socio-statistic and geographic information gathered while the visitor is reserving the spot or upon enrollment. (5)

Tourism is directly associated with accommodation facility that is a remarkable factor and has gained massive profits for the country. Several types of business accommodations are available such as hotels, resorts, motels, bed and breakfast, and guesthouses, etc. each category provide a difference of facilities, services and location. (9)

Several factors will play vital role in selection of the hotels by the travlellers, these factors are the individual favorites, spending power, locality charge, facilities provided by the hotels etc.

The study of Lewis $(1984,1985)$ identifies the major factor. The discoveries shows that area and cost were the determinant traits for lodging determination for both business and recreation explorers. (17)

The investigation of Knutson (1988) recognizes five main considerations that a continuous business explorer searches for while choosing a hotel:

- suitable location;

- comfortable and clean room;

- accessible facilities;

- security; and

- Responsive staffs.

The study of Cadotte and Turgeon (1988) analyse the collected data from members of American Hotel \& Motel Association (AH \& MA) on the frequent complements which are responsible for the selection of hotel by frequent travelers. They find the five major compliments those are:

- cooperative approach of staffs,

- hygiene of formation,

- effortlessness of establishment,

- quality of facility, and

- Staffs information of facility. 
Choose or Check-In: Gender Influence in Booking of the Luxury Hotels in Jaipur

The study of Atkinson (1988) identifies the major attributes used by the travelers in the selection of hotel are:

- Cleanliness of accommodation;

- Safety and security;

- Accommodation value for money; and

- Courtesy from staff.

The study of Taninecz (1990) traces the room cleanliness as one of the most critical factors decide the selection of hotel among the business travelers. The study of Marshall (1993) and Clow et al. (1994) concern itself with the safety \& security of guest during their stay at the hotel as major factor in deciding the hotel selection. (6)

According to him a guest is willing to shell out extra money for the above purpose. In fact safety \& security can be used as a major differentiating factor to fend off competition The study of Weaver and Oh (1993) emphasis the important factors perceived by business travelers in selection of a hotel. The study of Callen (1996) reemphasizes the importance of cleanliness in hotel selection. This study supports the findings of Taninecz (1990). (16)

The study of Raymond K.S. Chu, Tat Choi (1999) examine the factors perceived by the business \& leisure travelers in selecting a hotel in India.

The study of Locker (2002), brings out hygiene \& cleanliness occupy predominant place in the selection of hotel. His study further validates the Taninecz (1990) and Callen (1996). The study of Clow et al. (13)

(1994) have further validated the study of Marshall (1993) in identifying safety \& security as the major factor in the hotel selection. Therefore, the purpose of this study is to find the factors in the selection of luxury hotels.

\section{Methodology}

From five luxury hotels, a total of 200 guests were selected in Jaipur who are visited in the past one month and to assess the factors affecting hotel selection of the guests, a self-constructed questionnaire was used having.89 reliability and subjective validity. (9)

Permission for participation of guest was taken from the hotel manager. (10)

Before the administration of questionnaire, all the guests were explained about the purpose of the study and were ensured.

\section{TABLE -1 DesCRiPTIVE STATISTICS}

\begin{tabular}{|c|c|c|c|c|}
\hline $\begin{array}{l}\text { Factors } \\
\text { affecting } \\
\text { Hotel } \\
\text { Selection }\end{array}$ & Gender & $\mathbf{N}$ & Mean & SD \\
\hline \multirow[t]{2}{*}{ Location } & Male & 108 & 3.9 & 0.04 \\
\hline & Female & 92 & 4.12 & 0.1 \\
\hline \multirow[t]{2}{*}{ Price } & Male & 108 & 4.29 & 0.2 \\
\hline & Female & 92 & 3.67 & 0.41 \\
\hline \multirow[t]{2}{*}{ Experience } & Male & 108 & 0.17 & 0.32 \\
\hline & Female & 92 & 3.25 & 0.23 \\
\hline \multirow[t]{2}{*}{ Brand } & Male & 108 & 3.12 & 0.31 \\
\hline & Female & 92 & 4.69 & 0.21 \\
\hline
\end{tabular}

\begin{tabular}{|l|l|r|r|r|} 
Facilities & Male & 108 & 4.34 & 0.45 \\
\cline { 2 - 5 } & Female & 92 & 0.91 & 0.23 \\
\hline
\end{tabular}

\section{Conclusion}

Table 1 revealed the mean and standard deviation for male in context to location is 3.90 and 0.04 and for female is 4.12 and 0.10 , similarly mean and standard deviation for male in context to price is 4.29 and 0.10 and for female is 3.67 and 0.41 , similarly mean and standard deviation for male in context to past experience is 3.17 and 0.32 and foe female is 3.25 and 0.23 , similarly mean and standard deviation for male in context to brand is 3.12 and 0.31 and for female is 4.69 and 0.21 , similarly mean and standard deviation for male in context to facilities is 4.34 and 0.45 , and for female is 3.91 and 0.23 . Table 2 shown that there was a significant difference of location, price, brand and facilities among gender as the $\mathrm{p}$ - value $<.05$, while there was an insignificant difference of past experience among gender. Research findings have shown that gender plays an important role while selecting a luxury hotel. (8-12)

Table -2 Factor affecting theSelection of Hotel among Gender

\begin{tabular}{|c|c|c|c|c|}
\hline $\begin{array}{l}\text { Factors } \\
\text { affecting } \\
\text { Hotel } \\
\text { Selection }\end{array}$ & Gender & $\mathbf{N}$ & Mean & $\begin{array}{l}\text { p-value } \\
\text { based on } \\
\text { t-test }\end{array}$ \\
\hline \multirow[t]{2}{*}{ Location } & Male & 108 & 3.9 & \multirow[t]{2}{*}{$.000^{*}$} \\
\hline & Female & 92 & 4.12 & \\
\hline \multirow[t]{2}{*}{ Price } & Male & 108 & 4.29 & \multirow[t]{2}{*}{$.000 *$} \\
\hline & Female & 92 & 3.67 & \\
\hline \multirow{2}{*}{$\begin{array}{l}\text { Past } \\
\text { Experience }\end{array}$} & Male & 108 & 3.17 & \multirow[t]{2}{*}{0.488} \\
\hline & Female & 92 & 3.25 & \\
\hline \multirow[t]{2}{*}{ Brand } & Male & 108 & 3.12 & \multirow[t]{2}{*}{$.000 *$} \\
\hline & Female & 92 & 4.69 & \\
\hline \multirow[t]{2}{*}{ Facilities } & Male & 108 & 4.34 & \multirow[t]{2}{*}{$.000 *$} \\
\hline & Female & 92 & 3.91 & \\
\hline
\end{tabular}

\section{*significant; $\mathbf{p}<.05$}

\section{REFERENCES}

1. Bakewell, C. \& Mitchell, V. M., n.d. Male versus female consumer decision making styles. journal of business research, Volume 59, pp. 1297-1300.

2. Chen, P. C. \& Chen, Y. L., 2009. A comparison study of taiwan and US consumer decision making styles. thejournal of international management studies, 4(1), pp. 143- 153.

3. Čivre, P. Z. B. a. Ž., 2012. How do guests choose a hotel?. Academica Turistica, pp. 75-82.

4. Durvasala, S., Lysonki, S. \& Andrews, J., 1993. Cross cultural generalisability of a scale for profiling consumers decision making styles. Journal of Consumer Affairs, 27(1), pp. 33-75.

5. Hanzaee, K. H. \& Aghasibeig, S., 2008. Generation Y female and male decision making styles in Iran: are they different?. International Review of Retail, Distribution \& Consumer Research, 18(5), pp. 521-537.

6. Jocelyn Siah Chee Haoa, C. O. S. H., 2014. A study of preferences of business female travelers on the selection. Procedia - Social and Behavioral Sciences, pp. 176-186.

7. Lysonski, S., Durvasula, S. \& Zotos, Y., 1996. Consumer decision making styles: A multi country investigation. European Journal of Marketing, 30(12), pp. 10-21. 
8. Mokhlis, S., 2009. An Investigation of consumer decision making styles of young adults in Malaysia. International Journal of business \& management, 4(4), pp. 140-148. Ozgen, O. \& Kurt, S. D., 2013. Analysis of ecision making stylesof social media opinion leaders and seekers. Dokuz Evlul Universitesi Sosval Bilmler Enstitusudergisi, 15(2), pp. 253-266

9. Siu, Y. M., Hui, S. Y., Wang, C. L. \& Chang, M. K., 2001. An investigation of decision making styles of consumers in China. Journal of Consumer Affairs, Volume 35, pp. 326-345.

10. Sproles, E. K. \& Sproles, G. B., 1990. Consumer Decision making styles as a function of individual learning styles. The Journal of Consumer Affairs, 24(1), pp. 134-147.

11. Sproles, G. B., 79-85. Ffom perfectionism to dasaism; measuring consumers decision making styles. American council on consumer interest on Columbus, $\mathrm{OH}$.

12. Sproles, G. B. \& Kendall, E., 1986. A methodology for profiling consumer's decision making styles. The Journal of Consumer Affairs, 20(2), pp. 267- 279.

13. Walsh, G., Hennig- Thurau, T., Wayne- Mitchell, V. \& Wiedmann, K. P., 2001. Consumers' decision making style as a basis for market segmentation. journal of targeting, measurement \& analysis for marketing, 10(2), pp. 117-131.

14. Wesley, S., Lehew, M. \& Woodside,

15. G., 2006. Consumer decision making style and mall shopping behavior: builiding theory using exploratory data analysis and the comparative method. Journal of Business Research, Volume 59, pp. 535-548.

16. Yasin, B., 2009. the role of gender on turkish consumers decision making styles. advances in consumer research asia pacific conference proceedings,

17. Volume 8, pp. 301-308.

18. Yusoff, F. M. \& Abdullah, F. S., 2010. what really matters when choosing a hotel? the case of middle east tourists in Kuala lumpur, malaysia. Journal of Tourism, Hospitality \& Culinary Arts, Volume 5, pp. 55-62. 